\title{
The Prevalence of Smoking among Croatian Hospitalized Coronary Heart Disease Patients
}

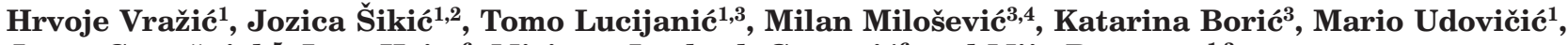 \\ Jasna Cmrečnjak ${ }^{5}$, Inge Heim ${ }^{6}$, Mirjana Jembrek Gostović ${ }^{6}$ and Mijo Bergovec ${ }^{1,3}$ \\ ${ }^{1}$ University of Zagreb, Dubrava University Hospital, Department of Internal Medicine, Division of Cardiology, Zagreb, Croatia \\ ${ }^{2}$ University of Zagreb, Sveti Duh University Hospital, Department of Internal Medicine, Division of Cardiology, Zagreb, Croatia \\ ${ }^{3}$ University of Zagreb, School of Medicine, Zagreb, Croatia \\ ${ }^{4}$ University of Zagreb, School of Medicine, »Andrija Štampar « School of Public Health, Zagreb, Croatia \\ 5 Čakovec General Hospital, Department of Internal Medicine, Division of Cardiology, Čakovec, Croatia \\ ${ }^{6}$ Institute for Cardiovascular Prevention and Rehabilitation, Zagreb, Croatia
}

\begin{abstract}
A B S T R A C T
The aim of this paper was to investigate the prevalence of smoking using selected anthropometric variables in a sample of hospitalized coronary heart disease (CHD) patients in Croatia ( $N=1,298)$. A total of 444 subjects (34.6\%) were non-smokers, 548 (42.6\%) were smokers and 293 (22.8\%) were ex-smokers. Men, on average, smoked more cigarettes per day than women (22.62 vs. 19.84 cigarettes, $p<0.001)$ and they also had bigger index "pack-years " than women (36.96 vs. 33.91, $p=0.024)$. Men were more often smokers and ex-smokers than women $(47.4 \%$ vs. $30.8 \%$ for smokers and $25.0 \%$ vs. $22.8 \%$ for ex-smokers, $p<0.001)$. In this study a high prevalence of smoking was found among CHD patients in Croatia. Unless it is decreased, it can be expected that CHD patients in Croatia will continue to experience adverse effects more often than other CHD patients in the rest of Europe.
\end{abstract}

Key words: coronary heart disease, cardiovascular risk factor, smoking, Croatia, prevention

\section{Introduction}

Research, conducted amongst the general population, has shown that smoking is not only an independent risk factor for the occurrence of coronary heart disease (CHD), cerebrovascular disease and atherosclerotic disease in general $^{1}$, but that it also increases total and cardiovascular mortality ${ }^{2-5}$. Smoking doubles the risk of cardiovascular death and it is estimated that approximately 30-40\% of all deaths from CHD are the result of smoking. It is considered to be the leading cause of premature death in Europe which can efficiently be prevented ${ }^{6}$.

It has been shown that smoking is also an independent risk factor for occurrence of type 2 diabetes mellitus ${ }^{7}$, which also accelerates progression of atherosclerosis and nephropathy ${ }^{8-10}$. Incidence of myocardial infarction is increased sixfold in women and threefold in men who smoke at least 20 cigarettes a day in comparison to people who have never smoked ${ }^{11,12}$. In the INTERHEART study (A global study of risk factors in acute myocardial infarction), which was conducted in 52 countries, it has been shown that smoking was responsible for $36 \%$ of attributive risk for occurrence of first myocardial infarction $^{13}$. Patients with established cardiovascular disease (CVD) who continue to smoke have an increased reinfarction risk as well as risk from death, which also includes sudden cardiac death ${ }^{14,15}$. On the other hand, it has also been shown that quitting smoking has a favourable effect on the prognosis of coronary disease ${ }^{16}$. Although smoking status before aortocoronary bypass procedure does not have an effect on postoperative survival, it has been shown that smokers who continue to smoke after this procedure have an increased risk of total mortality (RR 1.68), cardiac death (RR 1.75) and more frequently need repeated operative procedures (RR 1.41) in comparison with those who stopped smoking for at least a year ${ }^{17}$. Similar results have been obtained in a study which followed patients after percutaneous coronary in-

Received for publication September 1, 2011 
tervention and angioplasty. It was shown that smokers who continue to smoke have a higher relative risk of death (RR 1.76) and the occurrence of $\mathrm{Q}$ infarction (RR 2.08 ) in comparison with non-smokers, while they also have a higher risk of total and cardiac mortality (RR 1.44 and 1.49) in comparison with those that have stopped smoking ${ }^{18}$.

The advantages of stopping smoking in patients with CHD have been shown in a meta-analysis performed on 12,603 smokers who had myocardial infarction, aortocoronary bypass, angioplasty or known CHD. The relative risk of mortality in those that have stopped smoking in comparison with those who continue to smoke was $0.64^{19}$. Another cohort study performed on 2,619 patients who had a first myocardial infarction and were discharged from hospital has shown that in those who permanently quit smoking the risk had been decreasing, continually and significantly over time from the point of quitting smoking (RR 1.62 in period 0 to $<6$ months; RR 1.60 in period 6 to $<18$ months; RR 1.48 in period 18 to $<36$ months and RR 1.02 in period $>=36$ months $)^{20}$.

Smoking has also received a lot of attention in Croatia, both in general and specific populations. First reported data in literature, which is more than 30 years ago, showed that men smoked more frequently than women ${ }^{21}$. Data from Croatian Adult Health Survey (CAHS) from 2003 showed that $27.4 \%$ of Croatia's adult population smoked on a daily basis and that men were more often smokers than women ${ }^{22,23}$. Some authors propose that smokers should be divided into two groups - smokers who smoke up to 20 cigarettes per day and those who smoke more than 20 cigarettes per day and who can be considered heavy smokers ${ }^{24}$. According to this criterion, data from CAHS showed that men in Croatia were more often "heavy smokers" than women in all age groups, while most of women who are smokers could be classified as »light smokers" - meaning that they smoke up to 20 cigarettes per day ${ }^{25}$. There has also been some research performed in some specific populations. Of special interest is the data acquired from a study on health professionals and medical students in Croatia which showed that the frequency of smoking in this population is not favourable et all. ${ }^{26,27}$.

\section{Materials and Methods}

Our survey included 1,298 patients hospitalized between October $1^{\text {st }} 2007$ and January $7^{\text {th }} 2010$ for acute or chronic CHD in various hospitals in Croatia: Dubrava University Hospital (Zagreb), Sveti Duh University Hospital (Zagreb), Bjelovar General Hospital, Čakovec General Hospital, Karlovac General Hospital, Koprivnica General Hospital, Slavonski Brod General Hospital, Varaždin General Hospital, Rijeka University Hospital Centre, Pula General Hospital, Split University Hospital Centre, Dubrovnik General Hospital and Zadar General Hospital.

A special questionnaire was produced for this study which allowed recording of required data. The questionnaire was finalised after a series of consultations with ex- perts and literature and it was compiled using the model of large clinical trials conducted in Europe and Croatia [INTERHEART ${ }^{13}$, EUROASPIRE (European action on secondary prevention by intervention to reduce events) $\mathrm{I}^{28}$ and $\mathrm{II}^{29}$, EH-UH (Epidemiology of hypertension in Croatia) ${ }^{30}$, TASPIC-CRO (Treatment and secondary prevention of ischemic coronary events in Croatia) ${ }^{31}$ ]. This allowed the investigators to be able to efficiently compare results. Most of the questions had multiple answers offered in advance to achieve greater accuracy. Data was collected on patient history (personal and family history), age, sex and information on cardiovascular risk factors and discharge diagnoses. A physical examination was performed and its findings were recorded. The special focus in the questionnaire was on smoking.

Smokers were defined as persons who have smoked different forms of tobacco in the period of 12 months before the interview; this also includes those that have stopped smoking in those 12 months. Ex-smokers were defined as persons that have stopped smoking more than 12 months ago at the time of interview. In the questionnaire were recorded the forms of tobacco which were used (cigarettes, cigars, pipes, tobacco for chewing), smoking status (never, currently, stopped smoking), duration of smoking (age when a person began to smoke and when they stopped smoking) and number of cigarettes smoked per day. According to the data recorded in the questionnaire it was possible to calculate the index "pack-years" by multiplying the number of smoked cigarettes (in number of packs, where one pack contains 20 cigarettes) with duration of smoking (in years). This index is well accepted in literature as a measure of one's lifetime burden of smoking.

Data was collected by physicians or trained personnel (nurse), coded and entered into the electronic file. Confidentiality of data was ensured in accordance with current applicable codes, declarations and other provisions. The results are shown in tables, and for quantitative variables descriptive statistics were prepared with appropriate measures of central tendency and variability (mean, standard deviation, medians, associated interquartile ranges). Normal distribution of quantitative variables was tested by the Kolmogorov-Smirnov test, and then appropriate parametric (t-test for independent samples and analysis of variance - ANOVA) or nonparametric tests (Mann-Whitney U test, Kruskal-Wallis test) were used. The $\chi^{2}$ test was also used.

Statistically significant results were considered those with $\mathrm{p}$ values $<0.05$. Statistical analysis was made using the software PASW version 17.02 (Chicago Inc., IL, www.spss.com).

\section{Results}

In this article we analysed only data on tobacco consumption in the form of cigarettes, as other forms of tobacco consumption were reported in negligible frequencies. A total of 444 subjects $(34.6 \%)$ were non-smokers, 548 $(42.6 \%)$ were smokers and $293(22.8 \%)$ were ex-smokers. 
TABLE 1

SMOKING STATUS AMONG SUBJECTS BY SEX

\begin{tabular}{|c|c|c|c|c|c|c|c|c|c|c|}
\hline & \multirow{2}{*}{ Sex } & \multirow{2}{*}{$\mathrm{N}$} & \multirow{2}{*}{ Mean } & \multirow{2}{*}{$\mathrm{SD}$} & \multirow{2}{*}{ Min. } & \multicolumn{3}{|c|}{ Percentiles } & \multirow{2}{*}{ Max. } & \multirow{2}{*}{$\mathrm{p}$} \\
\hline & & & & & & 25. & 50. (Median) & 75. & & \\
\hline \multirow{2}{*}{$\begin{array}{l}\text { Duration of } \\
\text { smoking (years) }\end{array}$} & Men & 658 & 32.27 & 13.35 & 1.00 & 23.00 & 33.00 & 41.00 & 68.00 & \multirow{2}{*}{0.196} \\
\hline & Women & 178 & 34.08 & 13.73 & 4.00 & 25.00 & 33.00 & 44.00 & 71.00 & \\
\hline \multirow{2}{*}{$\begin{array}{l}\text { Average number of } \\
\text { cigarettes per day }\end{array}$} & Men & 663 & 22.62 & 9.33 & 1.00 & 20.00 & 20.00 & 20.00 & 100.00 & \multirow{2}{*}{$<0.001$} \\
\hline & Women & 178 & 19.84 & 8.40 & 1.00 & 20.00 & 20.00 & 20.00 & 60.00 & \\
\hline \multirow{2}{*}{ Index »pack-years« } & Men & 658 & 36.96 & 23.37 & 0.80 & 23.00 & 33.00 & 45.00 & 275.00 & \multirow{2}{*}{0.024} \\
\hline & Women & 178 & 33.91 & 23.40 & 2.60 & 20.00 & 30.00 & 42.00 & 162.00 & \\
\hline
\end{tabular}

$\mathrm{N}$ - number, SD - standard deviation, Min. - minimum, Max. - maximum

TABLE 2

SMOKING STATUS (3 GROUPS) BY SEX

\begin{tabular}{|c|c|c|c|c|}
\hline \multirow{2}{*}{ Sex } & \multicolumn{3}{|c|}{ Smoking status (3 groups) } & \multirow{2}{*}{ Total } \\
\hline & Never-smokers & Smokers & Ex-smokers (>12 months) & \\
\hline Male & $252(27.5 \%)$ & $434(47.4 \%)$ & $229(25.0 \%)$ & $915(100.0 \%)$ \\
\hline Female & $192(51.9 \%)$ & $114(30.8 \%)$ & $64(17.3 \%)$ & $370(100.0 \%)$ \\
\hline Total & $444(34.6 \%)$ & $548(42.6 \%)$ & $293(22.8 \%)$ & $1285(100.0 \%)$ \\
\hline
\end{tabular}

$\chi^{2}=69.185 ; \mathrm{df}=2 ; \mathrm{p}<0.001$

$\chi^{2}$ test was used, $\mathrm{p}<0.05$ is considered statistically significant

$\%$ - percent, $\mathrm{df}$ - degrees of freedom

It was also possible to divide subjects into two groups in relation to their smoking status: in the first group there were subjects that have never smoked (444 subjects, $34.6 \%$ ) and in the second group there were subjects who have experienced the harmful effects of tobacco - as it included those who were either ex-smokers or current smokers (841 subjects, 65.4\%).

As shown in Table 1, there were no statistically significant differences between men and women in the duration of smoking. There was, however, a statistically significant difference concerning the average daily number of smoked cigarettes and index »pack-years «. Men, on average, smoked more cigarettes per day than women $(22.62$ vs. 19.84 cigarettes, $\mathrm{p}<0.001$, Mann Whitney U test) and they also had bigger index "pack-years" than women (36.96 vs. 33.91, $\mathrm{p}=0.024$, Mann Whitney U test).

Comparison of subject's smoking status (3 groups: never-smokers, smokers and ex-smokers) by sex is shown in Table 2. Men were more often smokers and ex-smokers than women (47.4\% vs. $30.8 \%$ for smokers and $25.0 \%$ vs. $22.8 \%$ for ex-smokers, $\mathrm{p}<0.001, \chi^{2}$-test). When the subject's smoking status was divided only into 2 groups (Table 3, group 1: never smokers, groups 2: smokers and ex-smokers) men were statistically significantly more often in the group of smokers and ex-smokers than women (72.5\% vs. $48.1 \%, \mathrm{p}<0.001, \chi^{2}$-test).

\section{Discussion}

This article investigates the prevalences of smoking among CHD patients in Croatia. Smoking is a behav- ioural risk factor, thus its occurrence is completely dependent on one's behaviour ${ }^{32}$.

Tobacco use, most often in the form of smoking, has been shown to have deleterious effects on one's health ${ }^{1-5}$. Smoking has been shown to double the risk of death from CVD and it has been estimated that up to $40 \%$ of all deaths from CHD are a direct result of smoking. Therefore it is not surprising that smoking is the leading cause of premature death in Europe which can completely and effectively be prevented ${ }^{6}$. An illustrative example on the deleterious effects of smoking are the data from a study that showed that the incidence of myocardial infarction is increased sixfold in women and threefold in men who smoke at least 20 cigarettes a day in comparison with persons that have never smoked ${ }^{11,12}$.

Results were compared with two other relevant studies performed on CHD patients in Croatia within the last

TABLE 3

SMOKING STATUS (2 GROUPS) BY SEX

\begin{tabular}{lccc}
\hline \multirow{2}{*}{ Sex } & \multicolumn{2}{c}{ Smoking status $(2$ groups $)$} & \multirow{2}{*}{ Total } \\
\cline { 2 - 3 } & Never-smokers & Smokers* & \\
\hline Male & $252(27.5 \%)$ & $663(72.5 \%)$ & $915(100.0 \%)$ \\
Female & $192(51.9 \%)$ & $178(48.1 \%)$ & $370(100.0 \%)$ \\
Total & $444(34.6 \%)$ & $841(65.4 \%)$ & $1285(100.0 \%)$ \\
\hline
\end{tabular}

$\chi^{2}=69.084 ; \mathrm{df}=1 ; \mathrm{p}<0.001$

$\chi^{2}$ test was used, $\mathrm{p}<0.05$ is considered statistically significant

$\%$ - percent, df - degrees of freedom

* Smokers includes both current smokers and persons that have quit smoking more than 12 months before interview 
decade. The first was an international study - European action on secondary prevention by intervention to reduce events (EUROASPIRE) III study, performed in 22 European countries (one of which was Croatia, allowing comparison of data) in $2006^{33}$. The second study was performed in 2002 and 2003 on hospitalized CHD patients in Croatia - Treatment and secondary prevention of ischemic coronary events in Croatia (TASPIC-CRO) V study ${ }^{31}$.

In our study 548 patients $(42.6 \%)$ were smokers. This high prevalence of smokers shows that smoking in a population of CHD patients is similar to that of the general population $^{23}$ and that among CHD patients in Croatia smoking is higher than the European average $(17 \%)^{33}$ This prevalence is on the rise in Croatia (TASPIC-CRO V study reported smoking in $35 \%$ of CHD patients in Croatia) ${ }^{31}$. If those that have stopped smoking previously for more than 12 months are added to this number (who have also experienced deleterious effects of smoking), we can say that 841 subjects $(65.4 \%)$ have experienced those harmful effects of smoking, which is indicative for the important role of smoking as a cardiovascular risk factor in Croatia. Bearing in mind the type of population surveyed (CHD patients) such high prevalence is not so surprising as the connection between smoking and CHD is well known ${ }^{1,11,12}$.

Furthermore, there have been statistically significant differences in smoking between sexes - men smoke more cigarettes per day than women (Table 1, 22.62 cigarettes per day in men vs. 19.84 cigarettes per day in women, $\mathrm{p}<0.001$ ), and therefore men have higher index "pack-years" than women (Table 1, 36.96 in men vs. 33.91 in women, $\mathrm{p}=0.024)$. Men were also statistically significantly more likely to be smokers than women (Table 2 , $47.4 \%$ of men $v s$. $30.8 \%$ of women, $\mathrm{p}<0.001$ ). It is impor-

\section{R E F E R E N C E S}

1. JEE SH, SUH I, KIM IS, APPEL LJ, JAMA, 282 (1999) 2149. — 2 QIAO Q, TERVAHAUTA M, NISSINEN A, TUOMILEHTO J, Eur Heart J, 21 (2000) 1621. — 3. FOODY JM, COLE CR, BLACKSTONE EH, LAUER MS, Am J Cardiol, 87 (2001) 706. - 4. THE POOLING PROJECT RESEARCH GROUP, J Chronic Dis, 31 (1978) 201. - 5. NEATON JD BLACKBURN H, JACOBS D, KULLER L, LEE DJ, SHERWIN R, SHIH J, STAMLER J, WENTWORTH D, Arch Intern Med, 152 (1992) 1490. 6. YACH D, Tob Control, 14 (2005) 145 - - 7. PATJA K, JOUSILAHTI P HU G, VALLE T, QIAO Q, TUOMILEHTO J, J Intern Med, 258 (2005) 356. - 8. CHUAHIRUN T, KHANNA A, KIMBALL K, WESSON DE, Am J Kidney Dis, 41 (2003) 13. - 9. KARIM R, BUCHANAN TA, HODIS HN, LI Y, MACK WJ, Diabet Med, 22 (2005) 81. - 10. ORTH SR, SCHROEDER T, RITZ E, FERRARI P, Nephrol Dial Transplant, 20 (2005) 2414. 11. NJOLSTAD I, ARNESEN E, LUNDLARSEN PG, Circulation, 93 (1996) 450. - 12. PRESCOTT E, HIPPE M, SCHNOHR P, HEIN HO VESTBO J, BMJ, 316 (1998) 1043. - 13. YUSUF S, HAWKEN S, OUNPUU S, DANS T, AVEZUM A, LANAS F, MCQUEEN M, BUDAJ A, PAIS P, VARIGOS J, LISHENG L, INTERHEART STUDY INVESTIGATORS, Lancet, 364 (2004) 937. — 14. TOFLER GH, MULLER JE, STONE PH, DAVIES G, DAVIS VG, BRAUNWALD E, Am J Cardiol, 71 (1993) 1031. - 15. GOLDENBERG I, JONAS M, TENENBAUM A, BOYKO V MATETZKY S, SHOTAN A, BEHAR S, REICHER-REISS H, BEZAFIBRATE INFARCTION PREVENTION STUDY GROUP, Arch Intern Med, 163 (2003) 2301. - 16. VAN BERKEL TFM, BOERSMA H, ROOS-HESSELINK JW, ERDMAN RAM, SIMOONS ML, Eur Heart J, 20 (1999) 1773 - 17. VAN DOMBURG RT, MEETER K, VAN BERKEL DFM, VELDKAMP RF, VAN HERWERDEN LA, BOGERS A, J Am Coll Cardiol, 36 tant to note that such pattern of differences between sexes is also present in the general population, as shown in CAHS from $2003^{23,25}$. EUROASPIRE III study has also shown that male CHD patients are more frequently smokers than female CHD patients ${ }^{33}$.

Messages from this study become clearer when one remembers that it has been reported in literature that patients with established CVD who continue to smoke have an increased risk of reinfarction and an increased risk of death, which also includes sudden cardiac death ${ }^{14,15}$. Unless this high prevalence of smoking is decreased, it can be expected that CHD patients in Croatia will continue to experience the above mentioned adverse effects more often than other CHD patients in the rest of Europe. It is reassuring to some extent that it has also been shown in literature that stopping smoking has been proven to have beneficial influence on the prognosis of $\mathrm{CHD}^{16}$. This should serve as a strong stimulus to further concentrate our efforts to reduce smoking not just in the population of CHD patients, but also in the general population through more effective initiatives and interventions targeting primarily changes of lifestyle and bad habits.

\section{Acknowledgements}

This study was supported by the Ministry of Science, Education and Sports of the Republic of Croatia, project number 108-1080135-126 (Risk factors by region in hospitalised coronary heart disease patients, led by prof. Mijo Bergovec) which is a part of a programme of projects number 1080135 (Regionalism, dynamics of cardiovascular risk factors and health interventions, led by prof. Mijo Bergovec).
(2000) 878. - 18. HASDAI D, GARRATT KN, GRILL DE, LERMAN A, HOLMES DR, N Engl J Med, 336 (1997) 755. — 19. CRITCHLEY JA, CAPEWELL S, JAMA, 290 (2003) 86. - 20. REA TD, HECKBERT SR, KAPLAN RC, SMITH NL, LEMAITRE RN, PSATY BM, Ann Intern Med, 137 (2002) 494. - 21. PAVLOVIC M, COROVIC N, GOMZI M, SIMIC D, JAZBEC A, TILJAK MK, Coll Antropol, 28 (2004) 689. - 22. KOVACIC L, GAZDEK D, SAMARDZIC S, Acta Med Croatica, 61 (2007) 281. — 23. SAMARDZIC S, MARVINAC GV, PRLIC A, Coll Antropol, 33 Suppl 1 (2009) 43. - 24. O'CONNOR RJ, GIOVINO GA, KOZLOWSKI LT, SHIFFMAN S, HYLAND A, BERNERT JT, CARABALLO RS, CUMMINGS KM, Am J Epidemiol, 164 (2006) 750. — 25. SAMARDZIC S, PRISTAS I, MAVRINAC GV, Coll Antropol, 33 Suppl 1 (2009) 61. - 26. VRAZIC H, LJUBICIC D, SCHNEIDER NK, Int J Public Health, 53 (2008) 111. — 27. LJUBICIC D, SCHNEIDER NK, VRAZIC H, Public Health, 122 (2008) 1339. - 28. EUROASPIRE STUDY GROUP, Eur Heart J, 18 (1997) 1569. — 29. EUROASPIRE II STUDY GROUP, Eur Heart J, 22 (2001) 554 - 30. JELAKOVIC B, ZELJKOVIC-VRKIC T, PECIN I, DIKA Z, JOVANOVIC A, PODOBNIK D, SMUC T, GAMBERGER D, KATIC K, KASNER M, KUZMANIC D; EH-UH ISTRAZIVACKE SKUPINE, Acta Med Croatica, 61 (2007) 287. - 31. REINER Z, MIHATOV S, MILICIC D, BERGOVEC M, PLANINC D, TASPIC-CRO STUDY GROUP INVESTIGATORS, Eur J Cardiovasc Prev Rehabil, 13 (2006) 646. - 32. MULTIFACTORIAL TRIAL IN THE PREVENTION OF CORONARY HEART DISEASE STUDY GROUP, Eur Heart J, 3 (1982) 184. - 33. KOTSEVA K, WOOD D, DE BACKER G, DE BACQUER D, PYÖRÄLÄ K, KEIL U, EUROASPIRE STUDY GROUP, Eur J Cardiovasc Prev Rehabil, 16 (2009) 121. 
H. Vražić

University of Zagreb, Dubrava University Hospital, Division of Cardiology, Department of Internal Medicine, Av. G. Suška 6, 10000 Zagreb, Croatia e-mail:vrazic@gmail.com

\section{PREVALENCIJA PUŠENJA U HOSPITALIZIRANIH KORONARNIH BOLESNIKA U HRVATSKOJ}

\section{S A Ž E T A K}

Cilj ovog rada bio je pokazati prevalenciju pušenja uz izabrane antropometrijske varijable na uzorku bolesnika hospitaliziranih zbog koronarne bolesti u Republici Hrvatskoj ( $\mathrm{N}=1.298)$. Nikada nije pušilo 444 ispitanika $(34,6 \%), 548$ $(42,6 \%)$ ispitanika bili su pušači i 293 (22.8\%) ispitanika bili su bivši pušači. Muškarci su, u prosjeku, pušili više cigareta dnevno od žena $(22,62$ prema 19,84 cigareta, p<0,001) i također su imali veći indeks "pack-years « od žena $(36,96$ prema $33,91, p=0,024)$. Muškarci su češce bili pušači i bivši pušači nego žene $(47,4 \%$ prema 30,8\% za pušače i $25,0 \%$ prema $22,8 \%$ za bivše pušače, $p<0,001)$. U ovom istraživanju pronađena je visoka prevalencija pušenja kod bolesnika hospitaliziranih zbog koronarne bolesti srca u Hrvatskoj. Ukoliko se ona ne smanji, može se očekivati kako će ti bolesnici u budućnosti češće doživljavati štetne događaje nego koronarni bolesnici u ostatku Europe. 